\title{
Mutual Gains Success and Failure: Two Case Studies of Annual Hours in Ireland
}

Research Article

\author{
Lorraine Ryan* and Joseph Wallace
}

Dept. of Work and Employment Studies, Kemmy Business School, University of Limerick, Limerick, Ireland

\begin{abstract}
This paper examines the conditions under which annual hours (AH) are likely to succeed or fail and the role of workplace partnership in delivering mutual gains. We explore two case studies, in one company with a positive experience and in a second where $\mathrm{AH}$ were regarded as a failed initiative. The case studies are constructed from interviews with trade union and management representatives in the companies involved; from secondary sources and from a worker survey. The findings echo previous research that AH can deliver mutual gains in both the presence and absence of workplace partnership (Author and Author, 2016) and that delivery of real mutual gains is the key driver of the long term viability of $\mathrm{AH}$. However, the balance of mutual gains is subject to change and is strongly influenced by structural factors determining the suitability of $\mathrm{AH}$ to the particular enterprise.
\end{abstract}

Keywords: Mutual gains, workplace partnership, annual hours, exemplar case studies

(c) Sciendo

\section{INTRODUCTION}

The possibilities for mutual gains in the employment relationship have been subject to much debate by employment relations scholars (Ackers and Payne, 1998; Glover et al., 2013; Kelly, 1996, 2004; Kochan and Osterman, 1994). In the Irish context, mutual gains research has centred on the role of voluntary workplace partnership, given its underpinning by national level social partnership for some time (Dobbins and Gunnigle, 2009; Roche, 2009; Teague and Donaghey, 2009). Research has mostly focused on identifying the conditions considered necessary for mutual gains to arise from workplace partnership and analyses of the extent of the 'mutuality' of gains (Geary and Trif, 2011; Roche, 2009). However, it has now long been accepted that mutual gains arrangements have not diffused widely, and that collaborative bargaining or workplace partnership has not replaced traditional adversarial industrial relations to any extent (Teague and Hann, 2008). Belanger and Edwards (2007:713) note that 'conditions generating positive and sustainable outcomes for both capital and labour (or mutual gains) are feasible but rare'.

Annual (or annualised) hours ( $\mathrm{AH}$ ) is a flexible form of organising working hours, often introduced alongside workplace partnership, that has not been researched in great depth. Like workplace partnership, AH remains relatively rare in Ireland (White, 2010). Yet, research has shown the capacity of AH to deliver mutual gains, including improved workplace relations in both the presence and absence of workplace partnership (Arrowsmith, 2007; Ryan and Wallace, 2016). However, the limited extent of AH in Ireland suggests that the system is suitable only under a certain set of circumstances. In this paper, we examine two case studies where AH was introduced at around the same time. One case is a perceived success and a well-known exemplar of workplace partnership; the other is a perceived failure. We explore the capacity of $\mathrm{AH}$ to generate mutual gains and identify the factors that facilitate or constrain this. We find that many similar factors were present in both cases, although the process through which AH was introduced differed, with the successful company adopting a workplace partnership approach and the failed case making no major change to its industrial relations processes.

The paper is structured as follows: First, the concept of mutual gains is explored by drawing on two strands of literature: workplace partnership and $\mathrm{AH}$. While workplace partnership has been extensively examined by academics and practitioners, the $\mathrm{AH}$ literature offers a new perspective on mutual gains. It allows an exploration 
of a driver of mutual gains and the factors that influence this. The methodology is then detailed, and the two case studies are presented. A comparison of both case studies then allows factors to be highlighted that were present or absent in the successful and failed cases. The concluding analysis offers key observations on the factors that impact on the capacity of $\mathrm{AH}$ to generate mutual gains, the role of workplace partnership, and the importance of addressing over reliance on exemplar case studies in general.

\section{Workplace partnership and mutual gains}

Proponents of mutual gains argue that, while the interests of management and workers may diverge, there is also substantial overlap of interests for both and opportunities to create jointly shared benefits (Boxall, 2014; Cullinane et al., 2014). It is suggested that adherence to certain principles, processes and combinations of workplace practices can help to utilise this overlap of interests for the benefit of both (Guest and Peccei, 2001). Critics of the mutual gains premise, however, claim that cooperative relationships are unendurable because they are incompatible with the nature of industrial relations in a market economy (Kelly, 2004). Even where cooperative relationships do occur, these are often unsustainable in difficult economic circumstances. Butler and Tregaskis (2015) emphasise the temptation for management to withdraw from partnership as a result of short-term economic exigencies. There are also risks for the parties, particularly trade unions, of engaging in cooperative relationships, and implications for workplace representative's legitimacy (Butler and Tregaskis, 2015; Trif and Brady, 2013). Terry and Smith (2003:83) found that:

many rank-and-file members of trades unions remained uncertain and sceptical of activities which involved their officers 'getting into bed with' management, as some saw it, and thus unable to independently represent their interests.

This poses a dilemma for shop stewards, as it conflicts with their traditional role in representing employee interests, typically in opposition to management (Butler and Tregaskis, 2015).

A key focus of the mutual gains literature has been on workplace partnership and assessing the balance of gains for workers and management (Geary and Trif, 2011; Guest and Peccei, 2001; Roche, 2009). The problem with evaluating gains from workplace partnership, however, is that gains are often difficult to quantify, dependent on the perceptions of different stakeholders, and causality is not easy to establish. Arguably, direct views from workers are most important in evaluating gains. Workplace partnership as a concept has been plagued by definitional uncertainty and ambiguity (Martinez Lucio and Stewart, 2004). In general, it has been agreed that workplace partnership can be viewed as a bundle of principles and workplace practices which all need to be in place and which do not work as effectively alone (Guest and Peccei, 2001). Certain guiding principles at the strategic, functional and workplace level, such as management commitment, investment in training and development and employee involvement in problem-solving, are seen to be essential (Kochan and Osterman, 1994). Guest and Peccei, (2001:232) note:

there are dangers in seeking to be selective about what practices to support, since not all practices and elements of partnership have a positive effect and some do not if applied in isolation.

In order for workplace partnership to gain validity, they suggest:

identifying principles, practices and outcomes that are distinctly associated with those organisations that, on some basis, claim to be practicing partnership and are not present in other organisations.

One of the practices associated with workplace partnership is AH. It has been introduced in a number of companies, such as Wyeth Nutritionals, Irish Cement, the ESB and Rusal Aughinish Limited, as part of a broader change process and workplace partnership initiative (Higgins, 2005; Wallace, 2002). While the role of AH has been recognised in terms of productivity improvements and incentivising workers to work more 'smartly', it has heretofore been viewed as part of a partnership bundle (Dobbins and Gunnigle, 2009) and rarely examined in isolation. In this paper, we use $\mathrm{AH}$ as a way to examine mutual gains from a new angle. We present findings on mutual gains in Aughinish, a well-publicised case of a workplace partnership success story (Dobbins and Gunnigle, 2009). Alongside this, we examine a second case, a failure of $\mathrm{AH}$ in Drogheda Concentrates - a company that had many similar factors to Aughinish, such as high unionisation, increasing competition and high levels of overtime. At first glance, it appears 
that the major difference between the two cases is the process (workplace partnership versus traditional industrial relations) through which $\mathrm{AH}$ was introduced. Thus, workplace partnership is credited as the successful variable in creating mutual gains in Aughinish and it may be expected that the reason for the failure in Drogheda Concentrates was the absence of workplace partnership.

\section{Annual hours agreements and mutual gains}

$\mathrm{AH}$ agreements are a flexible form of work organisation with origins traced to developments in the pulp and paper industry in Scandinavia in the 1970s. Their introduction to Ireland dates to the early 1990s. AH operates by averaging hours worked across the year rather than the week or month. A yearly salary is paid on a regular basis, but hours worked can vary, as required, according to the season or demand. The system is designed so that employees work only when they are needed, thereby reducing idle time. Whereas in standard hourly work arrangements, peaks in demand are covered through overtime or employing temporary workers, $\mathrm{AH}$ allows for organisations to match working hours more closely to organisational demands (Arrowsmith, 2007; Bell and Hart, 2003; D'Arcy, 1998). A key attribute of $\mathrm{AH}$ is that overtime is normally eliminated. Typically, a number of 'reserve hours' are incorporated into yearly contractual hours, with some or all of these not being worked. These are essentially 'saved' hours, which can be used to cover for incidents such as absenteeism or sudden increases in demand. The idea is that workers get paid for a total number of hours, whether all of them are worked or not. The system acts as an incentive for workers to minimise the use of reserve hours, for which they are paid in advance and deters them from 'manufacturing' unnecessary overtime (Heyes, 1997).

$\mathrm{AH}$ is often portrayed as an innovative, mutual gains type of agreement and is said to involve a move from distributive towards integrative bargaining (Arrowsmith, 2007; Bell and Hart, 2003). The gains from AH are said to include stable salary (sometimes including improved pension and sick pay), better work-life balance, less reliance on overtime, and increased autonomy for workers. For management, gains include stable costs, improved productivity and efficiency, and the elimination of overtime and related grievances. AH is also said to involve improved relationships between management and workers (Amicus, 2005; Gall, 1996; Kouzis and Kretsos, 2003; Rodriguez, 2003).

\section{The suitability of annual hours: structural factors and impetus for change}

The literature proposes that certain factors are important in determining the suitability of $\mathrm{AH}$. It is suggested that $\mathrm{AH}$ is suited to seasonal industries or those that operate on a 24-hour basis, as it allows companies to cope with fluctuations in demand (Bell and Hart, 2003; Caroli et al., 2010; Hung, 1998). One of the main reasons for introducing $\mathrm{AH}$ is to eliminate overtime culture and its associated costs (Pasfield, 1999). The impetus for changing to $\mathrm{AH}$ often stems from a crisis situation and a necessity to revitalise a company's competitiveness. AH can often be accompanied by other broader changes in the organisation (Pasfield, 1999; Stredwick and Ellis, 2005) and is typically introduced through negotiation with trade unions (Arrowsmith, 2007; Bell and Hart, 2003; D'Arcy, 1998). We therefore expect structural factors to play a significant role in determining the success of $\mathrm{AH}$ in the cases studied.

\section{The role of trade unions and employment relations}

Trade unions often have significant input in negotiating, designing and implementing AH systems and in principle appear supportive of such agreements, once they are properly negotiated. Indeed, the complexity of AH agreements often requires collective bargaining on a range of issues (Arrowsmith, 2007; Ilsoe, 2010; Rodriguez, 2003; Stredwick and Ellis, 2005). Typically, agreements are tailored to suit each plant rather than adopting a 'one size fits all' approach, which reinforces the need for collective bargaining (Arrowsmith and Sisson, 2000; Caroli et al., 2010; D'Arcy, 1998). In an Irish context, AH agreements are found almost exclusively in unionised environments. Arrowsmith (2007) suggests that high-trust relationships between management and trade unions are a key factor in introducing and managing $\mathrm{AH}$, given the complexity of many $\mathrm{AH}$ schemes, and the need to secure employee consent, if they are to operate effectively. He suggests that the lack of high trust relationships is a possible explanation for the limited take-up of AH in the UK.

\section{Employee reactions}

While many writers emphasise the win-win nature of $\mathrm{AH}$, there are others of the view that $\mathrm{AH}$ works to the detriment of employees (Gall and Allsop, 2007; Gregory and Milner, 2009). Arguably, the extent to which employees benefit or not from $\mathrm{AH}$ depends on the specific provisions of the agreement and thus is linked to capacity of the trade union 
to negotiate a good deal. Employee resistance to $\mathrm{AH}$ has been the subject of a number of industrial disputes both in Ireland and the UK (Farrelly, 2009; Fitzgerald, 2001; Gall and Allsop, 2007) and is a key reason why companies do not proceed with AH (D'Arcy, 1998). Once AH is implemented, failure of management to consult with workers regarding changes to $\mathrm{AH}$ agreements can also be a source of conflict (Butler et al., 2011; Jenkins, 2008). Thus, we expect high levels of trade union input, high-trust relationship, and positive reactions from employees to be important in $\mathrm{AH}$ success and mutual gains.

\section{METHODOLOGY}

Research by White (2010) shows that the take-up of AH in Ireland is limited, but generally it has been successful where it has been introduced, with very few failures. This suggests that $\mathrm{AH}$ can deliver mutual gains, but only within a limited set of circumstances. The problem with identifying these limitations is that management case studies too frequently concentrate on success stories and avoid failures. Thus, it is often the case that factors associated with successful examples are uncritically identified as causal or critical to the success. Companies are often reluctant to have 'failures' investigated but only too ready to allow access to success stories. The absence of detailed case studies in which initiatives have failed precludes an examination of the extent to which similar factors may be present in both successful and unsuccessful cases.

To redress this imbalance, we set out to examine two cases of $\mathrm{AH}$ - one an acknowledged success and the other widely regarded as a failure. The successful example is Aughinish, where AH has been in operation for almost two decades (Dobbins and Gunnigle, 2009; NCPP, 2002; Wallace and White, 2007). The failure is in Drogheda Concentrates, where AH was introduced in 1997 and was abandoned, for general workers, shortly after its introduction. Yin (2003) argues that multiple case studies may be preferable to a single case. The rationale for using multiple cases focuses upon the need to establish whether the findings of the first case occur in other cases and, as a consequence, the need to generalise from these findings (Saunders et al., 2007). The intention here is that the unsuccessful case will identify common factors and isolate possible causal factors for success. Thus, the comparison of case studies provides important insights into the circumstances to which AH may be best suited, as well as highlighting the limitations of $\mathrm{AH}$ as an organisational choice.

Interviews were conducted with the HR Manager and the Managing Director of Aughinish, and two trade union officials from the Technical Engineering \& Electrical Union (TEEU) and the Services Industrial Professional and Technical Union (SIPTU). The TEEU and SIPTU officials involved in negotiating the AH agreement in Drogheda Concentrates were interviewed, and a telephone interview was conducted with the HR manager, which provided some insights into management's perspective on the case. However, the HR Manager involved in negotiating the $\mathrm{AH}$ agreement was no longer available. Follow-up telephone interviews were conducted with the HR Manager and union officials in Aughinish, following changes in the company climate. In total, 10 interviews were conducted between 2006 and 2010, lasting between 30 and 90 minutes. Interviewees were chosen according to their knowledge about $\mathrm{AH}$ and workplace partnership, and interviews were semi-structured in nature. Essentially, interviewees were encouraged to 'tell the story' of AH in each company, with interviewers prompting from a checklist of key issues identified from the literature. This included the rationale for introducing $\mathrm{AH}$, the level of involvement and support from trade unions, the role of workplace partnership, and perceptions of workers' attitudes towards $\mathrm{AH}$.

A survey of workers was also conducted in Aughinish. The relevant trade union shop stewards distributed questionnaires to all employees who worked AH. A total of 292 questionnaires were distributed and 82 were returned, giving a response rate of 28 per cent. The majority of respondents were males ( 96 per cent) aged over 40 years (72 per cent) and comprised craft workers and general operatives. The survey also sought qualitative comments from workers in relation to their views on $\mathrm{AH}$, workplace partnership, and mutual gains. The survey data, particularly the qualitative comments, provide useful information on workers' perceptions of a successful case of AH. It did not make sense, however, to survey workers in Drogheda Concentrates, as AH had been abandoned there. Secondary data from previously published sources and company documentation, including the agreements supplied to the researchers, were also reviewed. 


\section{RESULTS}

\section{Case study 1: Aughinish}

Rusal Aughinish Limited (previously Aughinish Alumina) is often cited as an exemplar company of workplace partnership (NCPP, 2002). The company employs around 450 permanent employees, the vast majority of whom are unionised in SIPTU, the TEEU and Amicus (Unite). In the 1980s, industrial relations at Aughinish were characterised by coercive management control, low-trust relationships, worker alienation, and frequent conflict. As a result, by the early 1990s, the closure of the plant was a real possibility and it became apparent to management and union officials that change was necessary. A radical unilateral overhaul of working arrangements was undertaken in 1993. This involved some 150 voluntary redundancies and a flat organisational structure with self-managing teams replacing the former hierarchical system. Although the change was introduced unilaterally, it was indicated during interviews that management had tacit union support and the change programme was not resisted. Furthermore, management did not see unilateral action as having long-term viability and indicated its commitment to 'doing business in a different way' in future. This was to take the form of workplace partnership.

The rationalisation was the first part of a change process and by the mid-1990s, to further reduce costs, the company sought the introduction of an $\mathrm{AH}$ system in response to the high levels of overtime. The company had 'analysed how [it could] offer the best possible pay and conditions to all employees while continuing to satisfy the plant requirements within [its] labour budget' (Aughinish 1996:4). The proposal involved introducing a high basic salary in return for an agreed number of $\mathrm{AH}$ that employees would work. In addition, there were 200 reserve hours that could be required to be worked, but it was specifically agreed that 'management and work teams [would] endeavour to minimise the use of reserve hours while ensuring the plant needs [were] adequately met' (Aughinish 1996:65).

As part of the new way of doing business, the company and unions engaged in training based on interest-based bargaining described in Getting to Yes, by Fisher and Ury (1983). This led to AH being introduced simultaneously with the development of workplace partnership. The trade unions and their members had considerable input to the design of the $\mathrm{AH}$ system and formal negotiations were characterised by interest-based bargaining. Consistent with a mutual gains approach, a joint monitoring and implementation group of workers and management representatives was formed to work on the details of the $\mathrm{AH}$ agreement and to monitor its operation. A senior management interviewee noted that both sides 'got it wrong' at times, but they worked together on these issues as they emerged, to sort them out before they became major problems. Despite this collaborative approach, considerable reservations continued to exist among employees and it took two years for the process of introducing $\mathrm{AH}$ to reach completion.

Our initial interviews with management and trade union representatives largely echoed previous research, with positive views of partnership, and mutual gains arising from $\mathrm{AH}$ for both workers and management. Union representatives identified a stable salary, a defined benefit pension scheme based on the enhanced salary, and a sick-pay scheme. The major benefit to workers was seen as the low percentage (around five to eight per cent) of reserve hours worked. Management informants identified a greater ability to predict and control labour costs, greater flexibility and the removal of overtime as a gain to the company. Employees no longer resist the use of contractors, as they now experience no loss of overtime earnings if contractors are employed. Management reported greater general efficiency and fewer plant shut-downs. Workers' concern to avoid having to work reserve hours has meant it is now in their interests to be efficient and get the job done as quickly as possible, with a notable emphasis on preventive maintenance to limit call-ins. Absenteeism also declined as result of teams self-regulating and limiting call-ins. Some gains were equally valued by both sides. There was a dramatic drop in disciplinary action and grievances, notably due to the elimination of overtime. Both union and management informants indicated that they valued the collaborative problem-solving approach to issues, which characterised what they saw as a highly developed level of partnership. Interviewees emphasised the gains that arose from $\mathrm{AH}$ and how these helped to develop and sustain the workplace partnership.

It's the one thing l'd say to people who are involved in a change process is that $A H$ is the wheel, that's the real thing ... you need that or there's nothing to back it [partnership] up. If you try it the other way, you're lost. AH came first, partnership came second because it's very easy to build a partnership when two people are focused on the one goal. And where we tried to bring in partnership with nothing underneath, we brought partnership into disrepute. (TEEU Official) 


\section{Permanency of mutual gains}

For many years, partnership and $\mathrm{AH}$ were mutually self-reinforcing arrangements. However, in 2008 the company experienced difficulty from a dramatic drop in demand for aluminium, as a result of the international recession. This led to short-time working. At the behest of new owners, it also saw management increasing the proportion of reserve hours that were worked. Management and union informants indicated that this led to a negative reaction from employees and that the worker survey conducted in late 2009 would likely have elicited more positive responses had it been conducted prior to the crisis. We found that 19 per cent of workers claimed they would vote to 'get rid of $\mathrm{AH}$ '. The key reasons given for this were perceptions that management was not operating according to the 'spirit of the agreement', with regard to the use of reserve hours, and was 'moving the goalposts'. This was reflected in the comments from workers, as outlined below.

If you asked me to fill out this form, one to two years ago I would be a lot different. I was very satisfied with it [AH] then. Now management are not abiding by the spirit of the agreement and it is turning me against it. (Worker $A$ )

Workers perceived a change in the balance of gains due to the impact of the external factors of a change in ownership and the economic climate.

At the moment our company is striving to claw back on bits that benefit employees and keep the bits that suit themselves.

(Worker B)

Company are not abiding by the terms and spirit of agreement. They are trying to take advantage of economic downturn and row back on agreement. (Worker $\mathrm{C}$ )

Workers also highlighted the effect the change in the balance of gains from AH had on their perceptions of workplace partnership. While many workers (31.6 per cent) still perceived $\mathrm{AH}$ to promote a partnership relationship, a significant proportion (38 per cent) thought it caused 'unions to be too much on management's side'.

AH worked fine until 2009. Management now wants more in my opinion and this greatly affects trust/partnership/ teamwork, all of which seemed to have been better prior to 2009 (Worker D).

Despite the diminution of gains due to the increase in use of reserve hours, we found that 72 per cent of workers would vote to retain $\mathrm{AH}$, as opposed to returning to overtime working, citing gains such as stable earnings and more time off. One worker noted that $\mathrm{AH}$ 'probably kept the company open in the current economic climate', and cited this as a reason for retaining it.

\section{Case study 2: Drogheda Concentrates Background}

Opened in 1975, Drogheda Concentrates is a subsidiary of the US multinational company Coca Cola, producing beverage bases for soft-drink products sold and exported around the world. At the time of the research, the plant employed 325 people. Employees at the plant were unionised and the main unions on site were SIPTU and the TEEU. In the late 1990s, employees were among the highest paid workers in the country and also benefitted from extremely high levels of overtime earnings. Over time, these high costs became unsustainable and compared unfavourably with the company's main competitor, a sister plant in France (Sheehan, 1997a). The plant came under pressure from the parent company to become more competitive, with additional business promised if productivity levels could be improved.

\section{The 'Plan for Change'}

In January 1997, the company launched the Plan for Change. It proposed to achieve cost reductions through the introduction of $\mathrm{AH}$, a reduction in numbers and other changes, such as teamworking, multi and cross-skilling, a new bonus system, and changes to pay structures (D'Arcy, 1998; Sheehan, 1997b). The company sought advice from the Irish Business and Employer's Confederation (IBEC), a UK consultant, and companies that had already implemented $\mathrm{AH}$, such as Aughinish. However, there was little involvement from trade unions or workers (D'Arcy, 
1998). The union was not opposed to $\mathrm{AH}$ in principle, but it was opposed to the lack of employee involvement and inadequate research on its application in the context of this company.

We were in support of $\mathrm{AH}$ because the basic principle was it gave our members a stable income ... but they forced it through and I wasn't happy with the deal. I just knew it wouldn't work.

(SIPTU Official)

The company also sought 100 voluntary redundancies and offered very attractive severance terms (Sheehan, 1997b). While the terms of the redundancies were attractive to a number of employees, the job losses themselves were a contentious issue with SIPTU and the employees who remained.

The $\mathrm{AH}$ element of the plan formed a key component of the cost-reduction strategy, with the expectation that $\mathrm{AH}$ would reduce the dependency on overtime and thus decrease costs and increase productivity. The company stressed the benefits of increased leisure time and the more stable earnings that would accrue to employees under the AH system. However, the AH system was not specifically tailored to the plant, and employees were sceptical about it. The negotiation of the Plan for Change was long and protracted, with involvement from the Labour Relations Commission (LRC) and the Labour Court (Labour Court, 1997). SIPTU members at the plant rejected the court's recommendation, with a SIPTU official claiming that 'it was impossible for the Labour Court to come up with a solution to it because both groups were that far apart'. Eventually, the company and SIPTU re-entered negotiations and the previously rejected Labour Court terms were used as the basis for the final settlement. AH, redundancies, performance-related pay, team-working, and an incremental pay system were agreed on. Employees achieved staged buy-in goodwill payments of 12 weeks' pay for agreeing to the changes (Sheehan, 1997c). The acceptance of the agreement was controversial, with workers interested in leaving the company tending to vote in favour, while a majority of those wishing to remain opposed the deal. Shortly afterwards, SIPTU workers began working AH at the plant.

\section{Initial experience of annual hours}

Initially, there were the familiar claims for success associated with the introduction of $\mathrm{AH}$, though these quickly evaporated. D'Arcy (1998) notes that the company claimed a 38 per cent increase per employee in productivity, which they said reduced the overall cost per unit. The company also claimed a change in the culture of the organisation, and that enhanced teamworking practices had led to greater flexibility and efficiency. This was a very premature view of the outcome and, within a few months of operating with $\mathrm{AH}$, it was clear that the initiative had badly failed.

Shortly after the introduction of $\mathrm{AH}$, the parent company, as promised, awarded a 60 per cent increase in business to the plant. This in turn led to employees having to work extra hours, eating into their reserve hours, which accounts for the claimed increases in productivity. Within a short time, problems with the scheduling of $\mathrm{AH}$ had occurred. D'Arcy (1998:46) notes 'hours had to be brought forward from later in the year and scheduled hours had to be adjusted on a constant basis'. To cope with the increase in demand, the company had to employ additional temporary workers. D'Arcy (1998:46) notes that:

$\mathrm{AH}$ had promised predictable hours of work and increased leisure time but neither of these benefits materialised. All of this led to employee dissatisfaction and loss of faith in the AH system.

The company was unable to cope with the increased demand, due to inadequate rostering of hours, inability to operate with the lower numbers of staff, strong employee opposition, and difficult relationships.

\section{The buy-out of annual hours}

After only a few months, management at the plant realised that $\mathrm{AH}$ was not working as they had anticipated and, following pressure from the parent company, a number of employees were either 'strategically relocated or given the opportunity to resign' (Management Interviewee). The new management decided to discontinue the AH system and revert to working weekly hours with overtime. However, it could not just be abandoned, and the company had to negotiate a buy-out with SIPTU workers. This was done directly with the workers as a group and outside normal negotiation channels, with neither SIPTU nor IBEC involved. Following months of negotiations, SIPTU workers received three increments on top of their salary (about 7.5 per cent) and a lump-sum payment to buy out $\mathrm{AH}$. 


\section{The craft group}

Although Drogheda Concentrates is widely regarded as having an $\mathrm{AH}$ agreement that went wrong, this was only the case for general workers, as the craft workers in the company continued to operate this system. The history of introducing AH for craft workers parallels that of general workers. In December 1997, craft workers and management at the plant were involved in a dispute in which both parties failed to reach agreement on the proposed terms of the Plan for Change. The dispute culminated in TEEU workers going on strike, which lasted about eight weeks and ended just before Christmas. The settlement included $\mathrm{AH}$, performance-related pay and team-working. As with SIPTU workers, craft workers received a series of 'goodwill' payments - four weeks' pay on three occasions over a 12-month period. In addition, the craft workers received a one-off payment in return for which the company gained freedom of access to contractors, where required (Sheehan, 1998). In contrast to the situation with SIPTU workers, craft workers continued to operate the AH system. This raises the question of why neither management nor the craft workers sought the abolition of $\mathrm{AH}$, as had happened with the SIPTU workers. The key difference is that in the case of craft workers, mutual gains were generated for both management and workers. A TEEU Official stated:

The tradesmen seemed to get a good deal out of it and it is working. You have an opportunity to vastly reduce the number of hours you spend on plant, but you have a commitment to spend extra hours if you have a major breakdown or something that demands your presence there. It also leads to high-quality delivery of product. People will tend to want to work off their own initiative because that's where they'll secure that there's less danger of being called in to work the reserve hours. It has a marvellous benefit from that end.

Workers gained from stable salary and fewer hours, while management improved efficiency and also the ability to employ contractors, which previously would have been a source of contention for craft workers, as they would have lost out on overtime. Reflecting on the case, a SIPTU official noted 'that's why it's very unfair to say that the AH was a failure, it wasn't. It was the company that was a failure'.

\section{DISCUSSION}

The use of the two case studies, one a perceived success and the other a perceived failure, provides a useful comparison to identify the circumstances under which AH works best and the factors that impact on mutual gains. It also limits the dangers associated with studying only exemplar cases. Earlier in the literature review, we identified key factors that we expect to be associated with successful $\mathrm{AH}$ and mutual gains. These were a workplace partnership approach to change, structural factors suited to $\mathrm{AH}$, high levels of trade union input, trust, and employee acceptance of AH. At first glance, it appears that AH succeeded in Aughinish and failed in Drogheda Concentrates, because the former adopted a workplace partnership approach. However, closer examination shows that mutual gains were generated for the craft group of workers in Drogheda Concentrates. As with Aughinish, these included increased employee autonomy, greater efficiency, and an improvement in relationships - gains often attributed to workplace partnership. Thus, examining the role of $\mathrm{AH}$ offers important insights into workplace partnership and mutual gains. In essence, there is a case of the proverbial 'chicken or egg?' i.e. does workplace partnership provide a collaborative environment in which AH can work? Or, does AH deliver mutual gains which lead to workplace partnership?

In fact, the two are cross-causal. While problem-solving and a partnership approach were significant in introducing $\mathrm{AH}$ in Aughinish, the high-level gains achieved through $\mathrm{AH}$ were most important in sustaining partnership and developing it to the level that existed until recently. Indeed, it is arguable that the dominant chain of causation is from $\mathrm{AH}$ to partnership. Rather than $\mathrm{AH}$ simply being only part of a workplace partnership 'bundle', we argue that the mutual gains generated by $\mathrm{AH}-$

of stable salary, fewer hours at work, greater autonomy, and efficiency - give credibility to workplace partnership. This credibility has been generally found to be lacking in Irish workplace partnership, arguably due to the amorphous nature of workplace partnership. A key finding of our research is the need for a driver to underpin workplace partnership and create mutual gains. However, it is not obvious, in normal industrial relations, for substantial mutual gains to be easily identified and the possibilities for $\mathrm{AH}$ as an organisational choice are limited. This confirms Belanger and Edwards' claim (2007:713) that conditions to generate mutual gains are 'feasible but rare'. 
At a minimum, the capacity to generate mutual gains from $\mathrm{AH}$ is linked to structural factors such as the type of work involved and crucially, as shown in the case of Drogheda Concentrates, the ability to operate without overtime. A key reason for moving to $\mathrm{AH}$ is elimination of overtime, so it is critical that overtime is not simply replaced with reserve hours. If low use of reserve hours can be achieved, as was the case in Aughinish and for craft workers in Drogheda Concentrates, then mutual gains can be realised in the form of better work-life balance, less time at work for a stable salary, less reliance on overtime, etc. If use of reserve hours is too high, then gains are not generated, as workers continue to work the same number of hours without the additional compensation of overtime and it is not surprising that they would oppose such a situation. The Aughinish agreement specifically set out that management and work teams would endeavour to limit the use of reserve hours. This is why AH is particularly suited to craft work or process industries where, once workers are incentivised, it is possible to find more efficient ways of working and reduce the number of hours spent on site. Often, only workers are able to identify causes of overtime that management may not know exist. While Drogheda Concentrates operated in a seasonal environment, which is a structural factor said to be suited to $\mathrm{AH}$, the system was unsuccessful due to a combination of factors, mainly the inability to operate without high levels of overtime.

The experience in Aughinish indicates that, contrary to suggestions, prior good relationships are not a requirement for initiating change. Indeed, the extremely poor relationships provided the incentive for change. However, the introduction of a complex $\mathrm{AH}$ system was seen to require a different relationship, supporting suggestions that collective bargaining and high-trust relationships can facilitate the move to $\mathrm{AH}$ (Arrowsmith, 2007; Bell and Hart, 2003; Ilsoe 2010; Rodriguez, 2003). In Drogheda Concentrates, management sought to negotiate change through the standard adversarial system, with no focus on reordering relationships. The lack of consultation meant that the AH system was not specifically designed for the plant - a factor highlighted as important in the literature (Arrowsmith and Sisson, 2000; Caroli et al., 2010; D'Arcy, 1998). Thus, the case studies seem to confirm the importance of consultation and gaining worker involvement in order for an $\mathrm{AH}$ system to be workable and mutual gains to arise. However, the experience among the craft workers in Drogheda Concentrates raises a contrary example and poses questions about such a simple diagnosis. Therefore, although the AH system was unsuccessful among general workers, it was retained for craft workers. This was despite the fact that there was a similar lack of planning, poor relationship, and initially employee opposition. What was crucially different, however, was that mutual gains were realised for craft workers but not for general workers. Management gained flexibility, while workers were able to work much shorter hours in return for a guaranteed high and stable salary. Thus, we see it is not intervening variables such as relationships, consultation and involvement, proper planning, etc. that drove the retention of $\mathrm{AH}$ for craft workers. Although the mutual gains were modest, compared to those in Aughinish, they were sufficient to see the system retained, and the elimination of overtime as a source of grievance led to an alleviation of the previously very poor relationships.

Geary and Trif (2010:67) highlight the importance of researching how workplace partnership arrangements that developed in favourable contexts might withstand new challenges, particularly from changes in economic forces. While the partnership arrangement in Aughinish developed initially from a crisis situation, the subsequent economic climate throughout the Irish 'Celtic Tiger' era was quite favourable and mutual gains were seen as somewhat evenly balanced between management and workers. As highlighted by Dobbins and Gunnigle (2009), one of the key reasons why mutual gains were perceived to be evenly balanced in Aughinish was because the company was insulated from market pressures. Our research shows that when market pressures were brought to bear on the company, reserve hours were increased, shifting the balance of gains towards management. When workers perceived the gains from $\mathrm{AH}$ to diminish this, in turn, the perceptions of workplace partnership were affected. A relatively high proportion of workers in Aughinish believed that unions were too much on the side of management, reflecting the risks for the legitimacy of union representatives when going into partnership with management (Butler and Tregaskis, 2015; Terry and Smith, 2003; Trif and Brady, 2013). Although the diminution in gains was arguably inevitable, given the downturn in the economic climate, many workers saw this change in the balance of advantage as a negative reflection of both $\mathrm{AH}$ and workplace partnership. They perceived management as operating outside the spirit of the agreement.

The case studies demonstrate that mutual gains can sustain a system of $\mathrm{AH}$, as among the craft workers in Drogheda Concentrates, without any substantial reordering of relations. A reordering of relationships, however, may lead to higher-level gains, as seen in Aughinish. Union involvement and worker cooperation in negotiating and operating $\mathrm{AH}$ systems can optimise the level of mutual gains, but the absence of such does not necessarily derail an $\mathrm{AH}$ system. Thus, while these factors may be important, arguably the most significant factor for successful 
implementation of $\mathrm{AH}$ is the capacity for mutual gains through limiting the use of reserve hours. This is most suited to certain types of work, notably process environments and craft work. Thus, AH has the capacity to generate mutual gains, but only within limited circumstances or work environments, which explains why the take-up of $\mathrm{AH}$ has been limited.

\section{Limitations and implications for future research}

Given the limited previous research on $\mathrm{AH}$, this paper provides important findings on the nature of such agreements and nuanced insights into the negotiation of change in both companies. As with any case study research, there are a number of limitations to the study. While the case of Drogheda Concentrates is dated, there are only a few cases in Ireland where AH has failed. It was, therefore, fortunate that the authors gained access to representatives with ready knowledge of the case, who could also supply secondary data (including a copy of the company agreement). In addition, the data explored are not greatly time sensitive and the issues examined are as relevant for companies introducing $\mathrm{AH}$ (or other changes in work practices) today, albeit within different contexts. Future research would benefit from longitudinal case study research to examine, in detail, the impact of changes in the external environment and the extent to which these put pressure on the capacity of $\mathrm{AH}$ to deliver mutual gains and stand the test of time. Perhaps one of the most important contributions of the paper is that it highlights the benefits of conducting comparisons between exemplar case studies and failures when examining work processes or new management techniques. This may prompt other researchers to adopt such an approach when examining other phenomena, and thus help to isolate and differentiate causal or critical factors to success from factors that may also be present in failed cases.

\section{CONCLUSION}

The two cases point to the importance of structural factors in limiting the suitability of AH systems. At a macro-level, this is indicated by their relatively low take-up. They are most suited to companies that operate on a 24-hour basis and have seasonal demand, as well as those that operate a high level of overtime (McMeekin, 1995; Spencer, 2001). Most importantly, there is a need for companies to be able to operate without high levels of overtime. The elimination of overtime is often the most difficult issue to resolve when moving to $\mathrm{AH}$, particularly if it has become 'guaranteed' or 'institutionalised'. Workers may strongly resist the abolition of established overtime or companies may find that they are simply unable to meet demand without it. Where favourable structural factors exist, AH can create incentives to realise the mutual gains and these gains can act to change the nature of interactions between management and workers, even leading to high-level partnership relationships. Workplace partnership, trust, and employee acceptance can be important in facilitating a move to $\mathrm{AH}$, but the absence of these factors does not necessarily prevent mutual gains.

\section{References}

Ackers, P. and Payne, J. (1998). 'British trade unions and social partnership: Rhetoric, reality and strategy'. International Journal of Human Resource Management, 9: 3, 529-550.

Amicus (2005). Annualised Hours, Amicus Guide, London: Amicus.

Arrowsmith, J. (2007). 'Why is there not more 'annualised hours' working in Britain?' Industrial Relations Journal, 38: 5, 423-438.

Arrowsmith, J. and Sisson, K. (2000). 'Working time', in S. Bach and K. Sisson (eds,) Personnel Management, $3^{\text {rd }}$ ed., Oxford: Blackwell.

Aughinish Alumina (1996). Annual Hours Agreement, Limerick: Aughinish Alumina.

Belanger, J. and Edwards, P. (2007). 'The conditions promoting compromise in the

workplace'. British Journal of Industrial Relations, 45: 4, 713-34.

Bell, D.N.F. and Hart, R.A. (2003). 'Annualised hours contracts: The way forward in labour market flexibility?' National Institute Economic Review, 185, 64-78.

Butler, P. and Tregaskis, O. (2015). 'Workplace partnership and legitimacy: A multi-layered analysis of the shop steward experience'. Work, Employment and Society, 29: 6, 895-911.

Butler, P., Glover, L. and Tregaskis, O. (2011). 'When the going gets tough'. . . : Recession and the resilience of workplace partnership'. British Journal of Industrial Relations, 49: 4, 666-687. 
Boxall, P. (2014). 'The future of employment relations from the perspective of human resource management'. Journal of Industrial Relations, 56: 4, 578-593.

Caroli, E., Gautié, J., Lloyd, C., Lamanthe, A. and James, S. (2010). 'Delivering flexibility: contrasting patterns in the French and the UK food processing industry'. British Journal of Industrial Relations, 48: 2, 284-309.

Cullinane, N., Donaghey, J., Dundon, T., Hickland, E. and Dobbins, T. (2014). 'Regulating for mutual gains? Non-union employee representation and the information and consultation directive'. The International Journal of Human Resource Management, 25: 6, 810-828.

D'Arcy, C. (1998). Annual Hours Report, Dublin: Employee Relations Information Unit, IBEC.

Dobbins, T. and Gunnigle, P. (2009). 'Can voluntary workplace partnership deliver sustainable mutual gains?' British Journal of Industrial Relations, 47: 3, 546-570.

Farrelly, R. (2009). 'Kemek - severance deal proposed', Industrial Relations News, 32, 09/09/2009.

Fitzgerald, K. (2001). 'Car test centre facing strike action', Industrial Relations News, 3, 17/01/2001.

Fisher, R. and Ury, W. (1983). Getting to Yes: Negotiating Agreement Without Giving In, New York: Penguin.

Gall, G. (1996). 'All year round: The growth of AH in Britain'. Personnel Review,

25: 3, 35-52.

Gall, G. and Allsop, D. (2007). 'AH working in Britain'. Personnel Review, 36: 5, 800-814.

Geary, J. and Trif, A. (2011). 'Workplace partnership and the balance of advantage: A critical case analysis' British Journal of Industrial Relations, 49: 2, 44-69.

Guest, D.E. and Peccei, R. (2001). 'Partnership at work: Mutuality and the balance of advantage'. British Journal of Industrial Relations, 39: 2, 207-236.

Glover, L., Tregaski, O. and Butler, P. (2013). 'Mutual gains? The workers' verdict: A longitudinal study'. The International Journal of Human Resource Management,

25: 6, 895-914.

Gregory, A. and Milner, S. (2009). 'Trade unions and work-life balance: Changing times in France and the UK?' British Journal of Industrial Relations, 47: 1, 122-146.

Heyes, J., (1997). 'Annualised hours and the 'knock': The organisation of working time in a chemicals plant'. Work Employment and Society, 11: 1, 65-81.

Higgins, C. (2005). 'Wyeth - partnership-based change plan kick-started by relationship training', Industrial Relations News, 5, 27/01/2005.

Hung, R. (1998). 'Novel ways to deal with seasonal manpower needs'. Work Study,

47: 3, 87-89.

Ilsoe, A. (2010). 'Between Trust and control: Company level bargaining on flexible working hours in the Danish and German metal industries'. Industrial Relations Journal, $\quad$ 4: 1, 34-51.

Jenkins, J. (2008). 'Pressurised partnership: A case of perishable compromise in contested terrain'. New Technology, Work and Employment, 23:3, 167-180.

Kelly, J. (1996). 'Union militancy and social partnership', in P. Ackers, C. Smith and P. Smith (eds), The New Workplace and Trade Unionism, London: Routledge.

Kelly, J. (2004). 'Social partnership agreements in Britain: Labour cooperation and compliance'. Industrial Relations: A Journal of Economy and Society, 43: 1, 267-292.

Kochan, T. and Osterman, P. (1994). The Mutual Gains Enterprise: Forging a Winning Partnership among Labor, Management and Government, Boston, MA: Harvard Business School Press.

Kouzis, G. and Kretsos, L. (2003). Annualised Hours in Europe, EIRO, Dublin. http://www.eurofound. europa.eu/eiro/2003/08/study/tn0308101s.htm [Accessed 28 November, 2018].

Labour Court, (1997). www.workplacerelations.ie http://www.workplacerelations.ie/en/Cases/1997/ November/LCR15638.html [Accessed 28 November, 2018].

Martínez Lucio, M. and Stuart, M. (2004). 'Swimming against the tide: Social partnership, mutual gains and the revival of "tired" HRM'. The International Journal of Human Resource Management, 15: 2, 410-424.

McMeekin, J. (1995). 'Why Tesco's new composite distribution needed $\mathrm{AH}$.'. International Journal of Retail \& Distribution Management, 23: 9, 36-38.

National Centre for Partnership and Performance, (2002). Case Study 2, Aughinish Alumina Ltd, Dublin: National Centre for Partnership and Performance.

Pasfield, J. (1999). Annual Hours Contracts and Working Time Transformation, Sussex: JP Associates.

Roche, W.K. (2009). 'Who gains from workplace partnership?' The International Journal of Human Resource Management, 20: 1, 1-33.

Rodriguez, M. (2003). 'Flexible working patterns using annualised hours', Work Study, 3, 145-149.

Ryan, L. and Wallace, J. (2016). 'Annual hours, mutual gains and workplace partnership: Exploring the links'. Employee Relations, 38: 2, 248-266.

Saunders, M., Lewis, P. and Thornhill, A. (2007). 
Research Methods for Business Students. Harlow: Pearson Education.

Sheehan, B. (1997a). 'Coca Cola Atlantic offers attractive severance deal'. Industrial Relations News, 5, 30/01/1997.

Sheehan, B. (1997b). 'Coca Cola - bid to find impasse over change plan'. Industrial Relations News, 37, 02/10/1997.

Sheehan, B. (1997c). 'Coca Cola - change plan gets the go-ahead'. Industrial Relations News, 38, 09/10/1997.

Sheehan, B. (1998). 'Coca Cola crafts strike settled after 3 weeks'. Industrial Relations News, 1/2, 08/01/1998.

Spencer, T. (2001). 'Arla's smart move'. Dairy Industries International, 66: 3, 31.

Stredwick, J. and Ellis, S. (2005). Flexible Working, London: Chartered Institute of Personnel and Development.

Teague, P. and Hann, D. (2008). Problems with Partnership at Work: Lessons from an Irish CaseStudy, Dublin: Labour Relations Commission.

Teague, P. and Donaghey, J. (2009). 'Why has Irish social partnership survived?' British Journal of Industrial Relations, 47: 1, 55-78.

Terry, M. and Smith, J. (2003). Evaluation of the
Partnership at Work Fund, London, Department of Trade and Industry.

Trif, A. and Brady, M. (2013). 'Implications of game theory for theoretical underpinning of cooperative relations in workplace partnership'. Industrial Relations Journal, $\quad 44: 3$, 258-275.

Wallace, J. (2002). 'Pacts for employment and competitiveness: Case studies, Irish Cement Ltd.'. Eironline [online], European Industrial Relations Observatory: Dublin.

http://www.eurofound.europa.eu/areas / industrialrelations/pecs/pdf/french/pecs_irish_ cement.pdf [Accessed 28 November, 2018].

Wallace, J. and White, L. (2007). 'Collaborative bargaining - annualised hours agreements in Ireland'. Paper presented at the 25th International Labour Process Conference, Amsterdam, April 2007.

White, L. (2010). 'Annual Hours Working in Ireland: An Exploration of its Extent, and Examination of the Experiences of Management, Unions and Workers'. Unpublished PhD, University of Limerick.

Yin, R.K. (2003). Case Study Research: Design and Methods, Thousand Oaks, CA: Sage Publications. 